\title{
The Constitutionality of Reverse Racial Discrimination*
}

\author{
John Hart Ely**
}

The problems were so intractable that this time it really looked like Fred and Ginger might not get together. But then Fred sang "I Used to be Color Blind,"1 and suddenly we knew that everything would turn out all right. Unfortunately, life is not an Astaire-Rogers musical-let alone one called, as this one was, Carefree - and though not being colorblind may begin to solve some of our problems, it raises serious new ones. If we are to have even a chance of curing our society of the sickness of racism, we will need a lot more Black professionals. And whatever the complex of reasons, it seems we will not get them in the foreseeable future unless we take blackness into account and weight it positively when we allocate opportunities. But that must mean denying opportunities to some people solely because they were born White. Either way, it's no musical, and I confess I have trouble understanding the place of righteous indignation on either side of this wrenching moral issue. ${ }^{2}$

On the surface at least, the constitutional issue is also quite troubling. We would not allow a state university to favor applicants because they are White, not even an iota, whether it called the adjustment a quota, affirmative action, or anything else. To allow it to favor applicants because they are Black seems to be countenancing the most flagrant of double standards. ${ }^{3}$

* An earlier version of this paper was presented and criticized at the Conference on Equality and Discrimination in American Law, held at The University of Chicago Law School on May 3-4, 1974, and jointly sponsored by the Law School and the Anti-Defamation League of B'nai B'rith.

** Professor of Law, Harvard University.

1 Irving Berlin, 1938 (ASCAP).

2 See also W. Kaufmann, Wrthout Guilt and Justice 74 (1973).

3 The debate on preferential admissions has been clouded by an inference that because a strictly "meritocratic" system of selection for law school or other places is best, it must also somehow be a constitutional requirement. The premise is maintainable, but the conclusion is not. Surely there is nothing uniquely "just" about distributing desirable lives to persons who were fortunate enough to be born smart (or tall, agile, or whatever.)

Naturally a deviation from the usual method will appear unjust to those who are accustomed to regarding ability to succeed as the correct criterion, but this appearance may be an illusion.

Nagel, Equal Treatment and Compensatory Discrimination, 2 PhIL. \& PUB. Afrs. 948, 360 
There is some authority, however, for the permissibility of "benign" racial classification. ${ }^{4}$ Closest to the mark, perhaps, is the Supreme Court's dictum in Swann v. Charlotte-Mecklenburg Board of Education, ${ }^{5}$ making explicit its view ${ }^{6}$ that a local community may bus children according to race, if it wishes, to remedy school segregation caused by residential patterns. ${ }^{7}$ No obvious distinctions come to mind by which voluntary busing plans can be distinguished from other "benign" discrimination. First, although the contrary claim is voiced all too frequently, ${ }^{8}$ it is incorrect to say that no one is hurt by busing. Children can be hurt by busing, not simply by the inconvenience of the transportation process itself, but also by the transition from a school environment in which they have grown secure to strange surroundings in which they are likely to find themselves in a racial minority for the first time. Second, the argument that busing hurts neither race more than the other-which may or may not be true, depending on the particular plan-is foreclosed, and rightly so, by cases like McLaughlin v. Florida ${ }^{9}$ and Loving $v$. Virginia. ${ }^{10}$ The fact remains that busing hurts people precisely because of their color. ${ }^{11}$ Third, it might be contended that, busing or no busing, every child will go to some school, whereas a preferential admissions program for a given law school will mean, after its effects have trickled down the entire law school hierarchy, that someone

(1973). A meritocratic system is efficient-it picks the people most likely to perform the tasks in question well-but the Constitution, which indeed sometimes indicates a preference for inefficiency, certainly conveys no general message that inefficient systems are unjust. Cf. Wellington, Common Law Rules and Constitutional Double Standards: Some Notes on Adjudication, 83 YaLE L.J. 221, 231 (1973). Thus serious constitutional objection can be made only to the use of racial criteria.

* See generally, e.g., Morris, Equal Protection, Affirmative Action and Racial Preferences in Law Admissions: DeFunis, v. Odegaard, 49 WASH. L. REv. 1, 20-24 (1973); Viera, Racial Imbalance, Black Separatism, and Permissible Classifications by Race, 67 Mrch. L. REv. 1553 (1969).

502 U.S. 1,16 (1971).

- See Ely, Legislative and Administrative Motivation in Constitutional Law, 79 Yale L.J. $1205,1291 \& \mathrm{n} .255$ (1970).

7 Thus the dictum was not addressed to a duty to remedy past de jure segregation; it dealt with, and legitimated, the use of race as a criterion of choice as part of a voluntary remedy for de facto segregation. The two situations are widely regarded as entirely different, though it is not entirely clear why they should be. See Developments in the Law-Equal Protection, 82 HARv. L. REv. 1065, 1108-09 (1969) [hereinafter cited as Developments].

8 See, e.g., DeFunis v. Odegaard, 82 Wash. 2d 11, 64-65, 507 P.2d 1169, 1199 (1973) (Hale, C.J., dissenting), dismissed as moot, 94 S. Ct. 1704 (1974). Cf. Morris, supra note 4, at 6-7.

8 379 U.S. 184 (1964).

10388 U.S. 1 (1967). See also notes 42 \& 49 infra.

11 Moreover, like the DeFunises, children in busing programs are singled out to bear disproportionately large shares of the costs of the social policy the state has decided to pursue. While this result is by no means unprecedented in the law, it must surely be an object of concern. 
will be completely denied the opportunity to go to law school because he is White. ${ }^{12}$ But even assuming this is so, ${ }^{13}$ it points to a difference in degree that probably should not go to the constitutional point. Places in desirable public schools are also scarce resources: an opportunity to attend some school is not the equivalent of an opportunity to attend the most desirable school in the area. ${ }^{14}$

The problem in relying on precedent here is that the Court has never told us what the constitutional point is. Voluntary busing plans may, for all we know, be approved by the Court for any of four reasons: (1) the state's goal, racial integration, is a "compelling" one;"15 (2) the use of a racial classification serves that goal perfectly and not approximately; ${ }^{18}$ (3) such plans are benignly motivated and therefore not "suspect" in the first place;17 or (4) the Court believes that even the most apparently "de facto" residential segregation has a bit of state action in its family tree, ${ }^{18}$ and that since busing has been imposed as a remedy for de jure segregation there would be no point in forbidding school boards to adopt similar methods. ${ }^{19}$ Or it may be-and the delayed dodge of DeFunis v. Odegaard ${ }^{20}$ strongly suggests this possibility ${ }^{21}$ that the Court simply cannot agree about the significance of its constitutional precedents. ${ }^{22}$

12 The idea would be that, although DeFunis was accepted at the Oregon, Idaho, Gonzaga and Willamette Law Schools, 82 Wash. 2d at $80 \mathrm{n.11}, 507$ P.2d at $1181 \mathrm{n} .11$, his decision to attend one of them would have displaced someone who would in turn have had to go elsewhere, until ultimately someone would have been excluded.

13 The argument assumes (1) that all places at all law schools are filled; (2) (and this seems most unlikely) that "the" Black applicant who (would have) displaced DeFunis at the University of Washington Law School would not have been admitted "on the merits" at any law school; and finally, (3) that the rejected applicant (after the trickle down effect) at the bottom of the law school hierarchy is White.

14 I hope I will pick up as many friends as I lose by suggesting that the difference may sometimes be as great as the difference DeFunis perceived between the University of Washington Law School and, say, the University of Oregon Law School. See note 12 supra. His preference was doubtless partially attributable to a desire to stay near home, but that only extends the parallel to busing.

$15 \mathrm{Cf}$. text and notes at notes 23-24 infra.

16 See notes 26 \& 49 infra.

17 Cf. note 26 infra.

18 See generally Keyes v. School Dist. No. 1, 413 U.S. 189, 201-02 (1973).

19 But cf. note 7 supra.

2094 S. Ct. 1704 (1974).

21 That the case was moot is an arguable proposition, but that it was less moot than other cases the Court has agreed to decide seems clear. See, e.g., Roe v. Wade, 410 U.S. 113, 124-25 (1973).

22 If the Court's apparent hope for an easier preferential admissions case is pinned on Justice Douglas's call in his dissent for a record that demonstrates that the Law School Admissions Test and other standard predictors predict less well for Blacks than for Whites, 
The standard constitutional defense of preferential treatment for Blacks accepts the principle that racial classifications are suspect and therefore subject to special, or unusually demanding, scrutiny. But that does not mean, the argument continues, that racial classifications are necessarily illegal: they can be justified, but only on the basis of a compelling state interest. It is true that the imposition of a compelling state interest requirement has generally been a prelude to invalidation. But surely, the argument concludes, the promotion of racial integration must be compelling enough. ${ }^{23}$ The words certainly flow in logical sequence, but simple assertions of relative importance can never wholly satisfy; one might again respond "double standard,"24 were "no standard" not obviously more appropriate. ${ }^{25}$

94 S. Ct. at 1713-18, it may be in for a disappointment. No such simple salvation seems imminent, for this is not a simple problem.

Existing evidence suggests that, to the extent there is a difference at all (and there seems to be little), the standard predictors work better for Blacks than Whites, and moreover that White students earn somewhat higher law school grades relative to their predictor scores than Black students. Schrader \&: Pitcher, Predicting Law School Grades for Black American Law Students (Educational Testing Service Rep. 1973). (And if the answer is that law school requirements are culturally biased-as they, and for that matter the requirements of the profession, undoubtedly are-one is surely entitled to ask what the ultimate remedy can be.) The cited study acknowledges certain limitations on its methodology, but for the moment we have nothing better.

The real hope lies, I think, in the fact that parents seem to make a difference. See Office of Education, U.S. Department of Health, Education, and Welfare, Equality of Educational Opportunity 298-302 (1966). But cf., e.g., Goodman, De Facto School Segregation: A Constitutional and Empirical Analysis, 60 CAIIF. L. REv. 275, 403-08 (1972). If we underwrite a generation of Black professionals, even a generation that does not do quite as well in professional school as their White classmates, their children and their children's children may grow up with interests, motivations and aptitudes that are not dissimilar from those the rest of us grew up with, and, consequently, may do as well in school as Whites from similar backgrounds. The case for "reparations" or payments for two hundred years of oppression may be an uneasy one, but those two hundred years cannot but have made a difference. No matter how plausible this reasoning sounds, however, it remains a speculation, and the question must be reached whether it can sustain what is, after all, a racial classification.

- 23 See, e.g., DeFunis v. Odegaard, 82 Wash. 2d 11, 32-35, 507 P.2d 1169, 1182-84 (1973), dismissed as moot, 94 S. Ct. 1704 (1974); Getman, The Emerging Constitutional Principle of Sexual Equality, 1972 SUP. CT. REv. 157, 168-69; O'Neil, Preferential Admissions: Equalizing the Access of Minority Groups to Higher Education, 80 YALE L.J. 699, 713-15 (1971); cf. Kahn v. Shevin, 94 S. Ct. 1734, 1739 (1974) (Brennan, J., dissenting) (footnote omitted):

I agree that, in providing a special benefit for a needy segment of society long the victim of purposeful discrimination and neglect, the statute serves the compelling state interest of achieving equality for such groups.

See also note 26 infra.

24 Cf. Roe v. Wade, 410 U.S. 113, 163-64 (1973).

25 Cf. A. Bickel, The Least Dangerous Branch 59 (1962): "So also must one view as a device of expediency a 'principle' that race is a proscribed ground of legislative classification, except that it may be used sometimes." 
I shall argue that reverse racial discrimination can be constitutional, but for reasons quite different from those in the conventional account. Rather than asserting that the demands of "special scrutiny" can be met -an assertion neither the Court nor anyone else has given us criteria for evaluating ${ }^{26}$ - I shall suggest that "special scrutiny" is not appropriate when White people have decided to favor Black people at the expense of White people. On one level there is a double standard here too: Whites can do things to Whites they could not do to Blacks. But on another, the principle I propose is a neutral one: regardless of whether it is wise or unwise, it is not "suspect" in a constitutional sense for a majority, any majority, to discriminate against itself..27

26 I have argued that, rhetoric to the contrary notwithstanding, special scrutiny in the suspect classification context has in fact consisted not in weighing ends but rather in insisting that the classification in issue fit a constitutionally permissible state goal with greater precision than any available alternative. J. Ely, Judicial Review of Suspicious Classifications: Why is Classification by Race Suspect and Should Classification by Sex Similarly be Subjected to Extraordinary Scrutiny?, Spring, 1971 (unpublished manuscript on file with the Yale Law Journal), summarized in Note, Mental Illness: A Suspect Classification?, 83 YALE L.]. 1237, 1245-50, 1251-52 (1974) [hereinafter cited as Mental Illness]. In order to support the constitutionality of preferential admissions, however, that argument requires the additional assumption that increasing the percentage of Black lawyers-as opposed to, say, reducing the percentage of Jewish lawyers-is a permissible state goal. I can reach that conclusion only by pursuing the analysis of this paper, see text and notes at notes 46 \& 51 infra, and yet that analysis demonstrates that the classification involved should not be subject to special scrutiny at all.

Nevertheless, to judge from Kahn v. Shevin, 94 S. Ct. 1734 (1974), this "tight fit" analysis, coupled with the conclusion that curing the profession's racial imbalance is a compelling state interest, is more likely to carry the day in the next "DeFunis" case than the "no suspect classification" analysis suggested in the remainder of this paper. In Kahn, three of the four Justices who were prepared to label sex a suspect classification in Frontiero v. Richardson, 411 U.S. 677 (1973), are of the opinion that special scrutiny is equally appropriate when women are being favored. See 94 S. Ct. at 1738-40 (Brennan, J., joined by Marshall, J., dissenting); id. at 1740 (White, J., dissenting). At least two of them, Justices Brennan and Marshall, are satisfied that aiding a class historically victimized by discrimination is a compelling state interest. See note 23 supra. But all three voted to invalidate the woman-favoring classification at issue in Kahn on the ground that it was imprecise relative to its purpose. In a "DeFunis" situation, however, once the goal of increasing the percentage of Blacks in the professions is accepted as either legitimate or compelling (whichever the Justice in question requires), the fit between a racial classification and that goal should present no problem. Justice Douglas, the fourth vote in Frontiero for the proposition that classifications by sex are suspect, appears not to regard special scrutiny as appropriate when the legislatively dominant class, in this case men, is being disfavored. See 94 S. Ct. at 1737 (Douglas, J., for the Court). But see DeFunis v. Odegaard, 94 S. Ct. 1704, 1713-16 (1974) (Douglas, J., dissenting).

27 Nonetheless, all racial classifications should be carefully examined to make sure they fall within the rather limited subset to which the more demanding standard of review is inappropriate. There are some racial classifications that do not merit "special scrutiny," but I cannot imagine one that does not merit a careful and skeptical look. See also text and notes at notes $50-53$ infra. 
The unconstitutionality of all racial discrimination, malign and benign alike, is sometimes urged on the ground that the fourteenth amendment, although it does not mention race, ${ }^{28}$ was enacted largely to outlaw racial discrimination. But the express preoccupation of the framers of the amendment was with discrimination against Blacks, that is, with making sure that Whites would not, despite the thirteenth amendment, continue to confine Blacks to an inferior position. ${ }^{29}$ That this is the amendment's history surely cannot conclude the matter; given the historical context, discrimination against Blacks is all the framers would have been concerned about, and the equal protection clause has rightly been construed to protect other minorities. But at the same time, the amendment cannot be applied without a sense of its historical meaning and function. Responsible inquiry must seek to determine the reasons why courts give unusually demanding scrutiny to classifications by which the dominant White majority has advantaged itself at the expense of Blacks, and to what extent those reasons apply where that majority chooses to disadvantage itself in favor of Blacks.

As a prelude, it may be useful to examine the manner and rationale of the ordinary ("rational relationship") review accorded ordinary ("nonsuspect") classifications under the equal protection clause. Consider a familiar example, a state statute that permits optometrists, but not opticians, to duplicate lenses. ${ }^{30}$ Consider further the plea of an optician who wishes to demonstrate that, although it may be true that most optometrists are better qualified to duplicate lenses than most opticians, he is in fact as well or better qualified to duplicate lenses than a number of optometrists he could name. The proffered proof would be rejected, on the theory that legislative classification on the basis of admittedly imperfect comparative generalizations-stereotypes, if you will-must be tolerated: unbearable cost would result if the government were obligated to create procedures for deciding each and every case on its merits.

Pushed to this concession, our optician's next argument would be

28 Cf. U.S. Consr. amend. XV.

29 See, e.g., Strauder v. West Virginia, 100 U.S. 303, 307-08 (1880); Slaughter House Cases, 83 U.S. (16 Wall.) 36, 81 (1873). See generally Frank \& Munro, The Original Understanding of "Equal Protection of the Laws," 50 CoLum. L. Rev. 131 (1950); Graham, Our "Declaratory" Fourteenth Amendment, 7 STAN. L. REV. 3 (1954).

30 See Williamson v. Lee Optical Co., 348 U.S. 483 (1955). Most classifications are of a similar "they-they" contour (see text at note 42 infra). See, e.g., Marshall v. United States, 94 S. Ct. 700 (1974) (two-time and three-time felons distinguished); Katzenbach v. Morgan, 384 U.S. 641, 657-58 (1966) (persons educated in Spanish at American-flag schools and persons educated in Spanish elsewhere distinguished). 
that although classifications rooted in comparative generalization are sometimes permissible, the unfairness that results to a number of individuals, himself included, from this classification is so great that it cannot be justified by the savings it effects. If the fit between classification and goal could be made tighter at no cost, the court might label the classification "irrational" and demand that it be made more discerning. ${ }^{31}$ But where, as in virtually every case involving real legislation, a more perfect fit would involve some added cost-either the cost to society of permitting some unqualified people to practice or the cost to the government of creating a case-by-case test of qualificationthe court would refuse to second-guess the legislative cost-benefit balance. There is no reason to suppose, at least in an "ordinary" case like this, that legislatures are any more likely than courts either to undervalue the unfairness of a rough or undiscerning classification or to overvalue the cost of reducing the incidence of unfairness. ${ }^{32}$

The usual point of departure from the realm of ordinary review is Justice Stone's "Carolene Products footnote," which may indeed point the way toward an acceptable mean between crabbed literalism in constitutional interpretation and a roving commission to correct social ills. For present purposes I refer to the suggestion that

prejudice against discrete and insular minorities may be a special condition, which tends seriously to curtail the operation of those political processes ordinarily to be relied upon to protect minorities, and which may call for a correspondingly more searching judicial inquiry. ${ }^{38}$.

The passage is a vague one, as Justice Rehnquist has recently reminded us: "It would hardly take extraordinary ingenuity for a lawyer to find 'insular and discrete' minorities at every turn in the road." 34 Indeed, in a sense the complainant in every equal protection case speaks for such a group: he would not be in court if the class in which the legislature had placed him were not, on at least one occasion, a political minority (they lost), both discrete (they're on the disfavored side of the line) and insular (they couldn't gather enough allies to defeat the legisla-

31 But cf. Williamson v. Lee Optical Co., 348 U.S. 483, 487 (1955): "The . . . law may exact a needless, wasteful requirement in many cases. But it is for the legislature, not the courts, to balance the advantages and disadvantages of the new requirement."

32 Cf. Oregon v. Mitchell, 400 U.S. 112, 247-48 (1970) (opinion of Brennan, Marshall, \& White, JJ.).

83 United States v. Carolene Products Co., 304 U.S. 144, 152 n.4 (1938). See also Hobson v. Hansen, 269 F. Supp. 401, 507-08 (D.D.C. 1967).

94 Sugarman v. Dougall, 413 U.S. 634, 657 (1978) (dissenting opinion). 
tion). ${ }^{35}$ Such tautologies demonstrate the perils of an excessively narrow frame of reference: in seeking criteria that identify the appropriate occasions for distrust, we must look beyond the state activity in the specific case at bar.

Two factors often mentioned to account for the special scrutiny accorded racial classifications ${ }^{36}$ are that racial minorities have been

35 See Karst, Invidious Discrimination: Justice Douglas and the Return of the "NaturalLaw-Due-Process Formula," 16 U.C.L.A.L. REv. 716, 724 (1969):

In Williamson, the losers in the legislature were not permanently disadvantaged minorities. The opticians might well have anticipated new legislative alliances that would soften the impact of this legislation by amendment.

But see id. at 724 n.39: "It has to be conceded that the opticians are still looking for such an alliance."

30 The immutability of the characteristic employed as the basis of classification is also often cited as a factor that should render a classification suspect. See, e.g., Frontiero v. Richardson, 411 U.S. 677, 686 (1973) (plurality opinion). The position, however, is difficult to maintain. Alienage-repeatedly held a suspect classification-is often an alterable status. (Ms. Griffiths, for example, was eligible for citizenship. In re Griffiths, 413 U.S. 717, $718 \mathrm{n} .1$ (1973).) On the other hand, classifications based on physical disability and intelligence are typically accepted as legitimate, even by the commentators who assert that immutability is relevant. Moreover, many characteristics that are theoretically changeable are not practically so; distinctions of constitutional magnitude should not partake of the pretense that any poor working man can significantly change his lot in life, or that any optician can become an optometrist, if he will only shape up. Most important, proponents of this view make no attempt-at least none that $I$ am aware of or can even plausibly imagine-to build a logical bridge from the immutability of the classifying characteristic to the conclusion that we should be suspicious of the classification. It is therefore no surprise that most discussions of immutability as a criterion have mentioned it only in passing, as neither an exclusive nor a requisite factor, and upon confronting the obvious counterexamples of disability and intelligence, have quickly added that those characteristics (unlike the one in issue) are often relevant to legitimate purposes. See, e.g., Frontiero v. Richardson, 411 U.S. 677, 686 (1973) (plurality opinion); Sail'er Inn, Inc. v. Kirby, 5 Cal. 3d 1, 18, 485 P.2d 529, 540, 95 Cal. Rptr. 329, 340 (1971). Such a "distinction" obviously completes the burial of what little point there was to the immutability factor in the first place. The argument is not entirely off the mark, however, as I shall suggest in note 43 infra.

A number of commentaries, seeking to distinguish benign from malign discrimination, and purporting to find support in Brown v. Board of Education, 347 U.S. 483, 494 (1954), argue that classifications disfavoring racial minorities are suspect because they "will usually be perceived as a stigma of inferiority and a badge of opprobrium." See Developments, supra note 7, at 1127. See also, e.g., DeFunis v. Odegaard, 82 Wash. 2d 11, 26-27, 507 P.2d 1169, 1179 (1973), dismissed as moot, 94 S. Ct. 1704 (1974); Sail'er Inn, Inc. v. Kirby, 5 Cal. 3d 1, 19, 485 P.2d 529, 540, 95 Cal. Rptr. 329, 340 (1971); Morris, supra note 4, at 19. Although this is an argument that supports my conclusion, I think it confuses two issues and thus misreads Brown. Feelings of opprobrium are relevant to determining whether an allegedly "harmless" classification, such as "separate but equal" schooling, in fact inflicts harm on one or the other class. But the existence of harm is not an issue in a DeFunis situation; the selection system in controversy quite tangibly disadvantages Whites. Nor can it be said that the presence of stigma is necessary in order to establish that there is the requisite amount of harm. That condition would make sense only if the Court more strenuously reviewed those distinctions that hurt the most. But outside the area of "fundamental interests" it generally follows no such course; a taxation 
subjected to legal disadvantage throughout our history, ${ }^{37}$ and that race is "generally ... irrelevant to any legitimate public purpose."38 Neither factor alone can adequately account for extraordinary scrutiny. Some minorities (extortionists, for example) have been repeatedly disadvantaged by the law with good reason. And the fact that a characteristic is irrelevant in almost all legal contexts (as most characteristics are) need not imply that there is anything wrong in seizing upon it in the rare context where it does make a difference. ${ }^{39}$ Still, these two factors in combination add up to something significant. The fact that a group has repeatedly been disadvantaged in ways that no one could rationally defend should make us suspicious of any legislation that singles out that group for disadvantage. There is reason to suspect that the prejudices that generated the plainly irrational legislation of past eras are also partly responsible for the facially more palatable classifications of the present day. That suspicion in turn would seem to support the Court's disinclination to credit the usually sufficient imperfect-butplausible statistical generalization in such contexts. ${ }^{40}$ For the usual

distinction worth $\$ 1,000,000$ receives the same review as one worth $\$ 100$-that is, virtually none.

There is the germ of a relevant consideration here too, though to see it one must shift focus from the perceptions of the discriminated-against to the perceptions of the discriminators. (The two will obviously be mutually reinforcing.) Comparative judgments that result in disfavoring a particular class may be rendered more "suspect" when the class thus disfavored is one that broad segments of the class doing the discriminating have historically written off as "inferior." See also note 45 infra.

37 E.g., Frontiero v. Richardson, 411 U.S. 677, 684 (1973) (plurality opinion); Note, The Legality of Homosexual Marriage, 82 YaLE L.J. 573, 577-78 (1973).

38 See Developments, supra note 7, at 1108. See also, e.g., Frontiero v. Richardson, 411 U.S. 677, 686 (1973) (plurality opinion).

39 See Tussman \& tenBroek, The Equal Protection of the Laws, 37 CALIF. L. REv. 342, 355-56 (1949); cf. Hirabayashi v. United States, 320 U.S. 81, 100 (1943).

10 Of course most judges, like most legislators, are white males, and there is no particular reason to suppose they are any more immune to the conscious and unconscious temptations that inhere in we-they generalization. Obviously the factors mentioned can distort the evaluation of a classification fully as much as they can distort its formation. But all this is only to suggest that the Court has chosen the right course in reviewing classifications it has decided are suspicious-a course not of restriking or secondguessing the legislative cost-benefit balance but rather of demanding a congruence guessing the legissifice
between the classifican and its goal as perfect as practicable. When in a given situation you can't be trusted to generalize and I can't be trusted to generalize, the answer is not to generalize-so long as a bearable alternative exists. And here, the Court has recognized, one does-the alternative of forcing the system to absorb the additional cost that case by case determinations of qualification will entail. Legislatures incur this cost voluntarily in a great many situations, and courts have on other occasions forced them to do so where constitutionally protected interests will be threatened by an imperfectly fitting classification. The unusual dangers of distortion that inhere in a we-they process of comparative generalization, the Court seems to have been telling us in the racial classification cases, also demand that we bear the increased cost of individual justice.

Ely, The Wages of Crying Wolf: A Comment on Roe v. Wade, 82 Yale L.J. 920, 933 n.85 (1973). 
mode of review assumes that legislatures can generally be trusted to appreciate the unfairness of a loose fitting classification and objectively balance that unfairness against the savings it effects. Where there is unusual reason to suspect a legislative desire generally and irrationally to subjugate the group disadvantaged by the classification, however, this usual assumption seems an inappropriate basis for a system of review.

Of course, it cannot be said with assurance that all classifications by race that disadvantage minorities were intended to do so. ${ }^{41}$ The word, however, is "suspect." The soundness of the Court's decision to treat these classifications with suspicion, irrespective of what can actually be proved about the legislature's underlying motivation, is corroborated by another point of distinction from the usual classification (to which the "rational relationship" standard is applied). Racial classifications that disadvantage minorities are rooted in "we-they" generalizations and balances as opposed to "they-they" generalizations and balances. Few legislators are opticians; but few are optometrists either. Thus, although a decision to distinguish opticians from optometrists incorporates a stereotypical comparison of two classes of people, it is a comparison of two "they" stereotypes, viz., "They [opticians] generally differ from them [optometrists] in certain respects that we find sufficient on balance to justify the decision to classify on this basis." Legislators, however, have traditionally not only not been Black; they have been White. A decision to distinguish Blacks from Whites therefore has its roots in a comparison between a "we" stereotype and a "they" stereotype, viz., "They [Blacks] differ from us [Whites] in certain respects that we find sufficient on balance to justify the decision to classify on this basis." 42

11 Who is to say that the majority of a legislature which enacts a statute segregating the schools is actuated by a conscious desire to suppress and humiliate the Negro? Who is to say that for many members more decent feelings are not decisive-the feeling, for example, that under existing circumstances Negro children are better off and can be more effectively educated in schools reserved exclusively for them, and that this is the most hopeful road to the goal of the equality of the races under law?

A. BICKEx, supra note 25, at 61-62 (1962). Or, perhaps more plausibly, racial segregation may have been based on a feeling that Blacks were "different," and therefore had a different "place" in the proper scheme of things-coupled with an unfeeling assumption that because we aren't bothered by segregation, they won't be either. In asserting that segregation will hurt only if Blacks choose to let it hurt, the majority in Plessy v. Ferguson, 163 U.S. 537, 551 (1896), convicted itself not so much of racial prejudice as of the lesser included offense of gross insensitivity.

42 The statutes invalidated in McLaughlin v. Florida, 379 U.S. 184 (1964), and Loving v. Virginia, 388 U.S. 1 (1967), treated Blacks no worse than Whites. In addition to having obvious roots in racial prejudice, however, the statutes did discriminate against (a) racially mixed couples and (b) persons wishing to marry outside their race-both of which are they-groups. 
The choice between classifying on the basis of a comparative generalization and attempting to come up with a more discriminating formula always involves balancing the increase in fairness that greater individualization will produce against the added costs it will entail. But in we-they situations two dangers inherent in this balancing process are significantly intensified. The first is that legislators will overestimate the costs of bringing "them" into a position of equality with "us." But the balance is likely to be skewed in another, though related, waythrough an undervaluation of the countervailing interest in fairness. It is no startling psychological insight that most of us are delighted to hear and prone to accept characterizations of ethnic or other groups that suggest that the groups to which we belong are superior to others. ${ }^{43}$ The second danger is therefore one of overestimating the fit of the proposed stereotypical classification. By seizing upon the positive myths about our own class and the negative myths about theirs, or for that matter the realities respecting some or most members of the two classes, legislators may too readily assume that not many of "them" will be unfairly deprived, nor many of "us" unfairly benefitted, by the proposed classification. .4 $^{4}$

13 The analysis suggested in the text probably should be limited to situations where most of the "we"s have always been, and expect to remain, "we"s, and will therefore have difficulty being objective about precisely what the difference entails. $C f$. Ferguson v. Skrupa, 372 U.S. 726 (1963). But cf. Note, Mental Illness, supra note 26, at 1253. Classifications based on youth or age should therefore be excluded from the suspicious category. Classifications disadvantaging aliens, on the other hand, might properly be regarded with suspicion. For even though alienage is an alterable status, cf. note 36 supra, most legislators are, and consequently have always been, native-born citizens.

14 By speaking in we-they terms, I am not suggesting the existence of permanent "have" and "have not" classes with respect to legislative power. The majority with respect to a given issue comprises an amalgam of various interest groups, which may array themselves quite differently on other issues. See, e.g., Auerbach, The Reapportionment Cases: One Person, One Vote-One Vote, One Value, 1964 Sup. Cr. REv. 1, 52. My suggestion is rather that there will be occasions on which a majority of the decision making body belongs to the class that is comparatively advantaged (or, as in the DeFunis situation, disadvantaged) by the distinction it has drawn. It makes no sense in terms of the analysis here proposed to talk of "we"s and "they"s without reference to the classification in issue.

There is, of course, a danger of a sort of distortion when the lobby for an interest group is unusually strong. Cf. R. POSNER, ECONOMIC ANALYsIS OF LAw 271 (1973). Although the laws that emerge from such situations may be somewhat suspicious, it is difficult to see how the Court could react other than as it has, by refusing to undertake the investigation invited by the complainant. See, e.g., Daniel v. Family Sec. Life Ins. Co., 336 U.S. 220 (1949). There is probably some psychological difference here. Political support may induce a legislator to swallow his scruples and draw an optometrist-optician line in circumstances where he knows substantial unfairness will accrue to a number of opticians; but where the line is we-they he is less likely even to see the unfairness. The more important distinction, however, is an institutional one. Courts usually cannot know (and probably should not announce when they do know) the extent to which various members of the 
An understanding of why the Court has approached racial classifications that disadvantage minorities with suspicion unfortunately generates no bright line test to determine whether other, nonracial minorities should receive similar protection. ${ }^{45}$ The implication of that

legislature are under the thumbs of various lobbies, cf. Fletcher v. Peck, 10 U.S. (6 Cranch) 87, 130 (1810); United States v. Des Moines Nav. \& Ry. Co., 142 U.S. 510, $544-45$ (1892), but they can tell when a legislature is predominantly White. (And if the makeup of the legislature is less certain they should apply special scrutiny to the racial classification. See text and notes at notes 58-59 infra.) Arguably it is more appropriate for state courts to take local political pressures into consideration. See W. LOCKHART, Y. KAMISAR \& J. CHOPER, Constitutional LAW 481 (3d ed: 1970), and sources cited.

45 Lest sight of the dog be lost in a preoccupation with the tail, $\dot{I}$ should stress the limited function of the we-they analytic framework in this paper. I have tried to identify the factors that have made racial classifications that disfavor minorities suspect, in an effort to see whether those factors are applicable when a majority disadvantages itself. In that context $I$ have suggested that the we-they nature of these classifications has been one factor that has properly buttressed the more obvious factor of racial prejudice.

It may be worth considering briefly, however, whether a we-they relationship between the makers and the "victims" of regulation should itself become the basis for special scrutiny, sufficient to generate "new" suspect classifications without the coexistence of the prejudice component. Many people would doubtless reject that idea as overbroad, on the ground that most legislation is we-they on its face: a privilege is extended to, or a restriction is imposed upon, a defined group, and no one else is mentioned. They might argue that it is impossible to draw a line between situations in which the legislators were comparing the designated class with some subset of persons (like opticians) "just barely" outside the class, and those in which they were comparing the designated class with everyone else (including themselves). The claim would be that the psychological insights of the we-they analysis pertain only to the latter kind of comparison. I am not convinced that this line needs to be drawn. Whenever a designated minority is singled out for special deprivation, and everyone else is left unregulated, I am not greatly troubled by treating the classification as suspect-and therefore upholding it only when it is closely tailored to its goal, see note 26 supra-if it is obviously rooted in a relative judgment concerning the characteristics of the people distinguished. But cf. Note, Mental Illness, supra note 26, at 1253-54. (Of course, if a they-group is granted a distinctive benefit, there is no need for special scrutiny. That is the main point of this paper.) $I$ have already suggested a significant limitation: confining the theory to cases in which the "we"s, by and large, have always been and expect to remain "we"s. See note 43 supra.

If this suggestion of a broadened definition of suspect classifications seems too extreme, there are various ways to narrow it. One approach would limit special scrutiny to situations where the "they" group is one that broad segments of the "we" group have historically regarded as inferior. The suggested modification is difficult to apply-Blacks seem to be such a group; Jews do not; women claim they are, but surely that is an in-between case. In addition, the narrowed approach is unduly restrictive. (Under this approach it probably would not be suspect for a predominantly Black legislature to favor Blacks at the expense of Whites-and that strikes me as an unentertainable result.)

Another way to narrow the theory's impact would be to require not only that the classification be we-they, but also that the "they" group be unusually impotent politically. See Note, Mental Illness, supra note 26, at 1254-58. In most of the cases I have indicated, this would not make a difference. Cf. note 43 supra. It seems to me, however, that the suggested superimposition represents a retreat from the comparative (though it is no more 
understanding for the present discussion, however, seems obvious. When the group that controls the decision making process classifies so as to advantage a minority and disadvantage itself, the reasons for being unusually suspicious, and, consequently, employing a stringent brand of review, are lacking. A White majority is unlikely to disadvantage itself for reasons of racial prejudice; nor is it likely to be tempted either to underestimate the needs and deserts of Whites relative to those of others, or to overestimate the costs of devising an alternative classification that would extend to certain Whites the advantages generally extended to Blacks. ${ }^{48}$ The conclusion is corroborated by the realization, given eloquent voice in Justice Jackson's Railway Express opinion, ${ }^{47}$ that the function of the equal protection clause is in large measure to protect against substantive outrages by requiring that those who would harm others must at the same time harm themselves-or at least widespread elements of the constituency on which they depend for re-election. ${ }^{48}$ But the argument does not work the other way around: similar reasoning supports no insistence that one cannot hurt himself, or the majority on whose support he depends, without at the same time hurting others as well.

than comparative) clarity of the we-they specification of the Carolene Products footnote. See text and notes at notes 34-35 supra. Indeed, one would have to question the appropriateness of treating the paradigm case-the racial classification that disfavors Blacks-as a suspect classification. See, e.g., Goodman, supra note 22, at 813:

[I] indeed there are groups that have no voice or visibility and that, in an almost literal sense, cannot make themselves heard, it is by no means clear that the urban black is among them. Numerically, blacks approach a majority in many large cities and are an increasingly formidable voting bloc in most. Numbers aside, they speak with a voice ever more audible ....

Perhaps, assuming a disposition to narrow the impact of the theory, the soundest policy is to limit the theory to the more obvious cases of we-they thinking: Black-White, malefemale, Catholic-Protestant-Jew, nonpoor-poor. (There are problems, however, in applying the theory to so-called wealth discrimination cases. Most of these cases arise in a user charge situation and therefore involve de facto discrimination, as opposed to explicit classification based on wealth. It is therefore hard to detect in these cases any generalization concerning the relative characteristics of the classes involved. In addition, if special scrutiny is means scrutiny, see note 26 supra, it is worth noting that user charges generally fit their purposes rather well.) Respecting religious classifications, see note 59 infra.

46 Of course, the legislative goal may be defined in a way that would render extension of the advantage to any Whites at all senseless-as where the goal is not aiding the culturally disadvantaged generally, but rather curing the underrepresentation of Blacks in the legal profession. In that instance the point would be that there is no special reason to be suspicious of a White legislature's decision to pursue that goal.

47 Railway Express Agency, Inc. v. New York, 396 U.S. 106, 111-13 (1949) (Jackson, J., concurring). See also Buel, Democracy and the American Revolution: A Frame of Reference, 21 WM. \& MARY Q. 165, 182-85 (1964).

18 See also Kurland, Egalitarianism and the Warren Court, 68 MICH. L. REv, 629, 674 (1970): "The purpose of the clause was to prevent majorities from imposing on minorities by way of laws that provide different rules for the one than for the other." 
Of course, there will be cases in which it will not be clear whether the legislative majority or the allegedly benefitted minority has ended up, on balance, with the comparative advantage-or, more to the point, whether the decision makers intended a greater benefit to the "we"s or the "they"s. In these cases we should be suspicious. ${ }^{49}$ Furthermore, preoccupation with a majority-minority analytic framework should not obscure the fundamental premise that racial and related prejudices can properly give rise to suspicion. Such prejudice could obviously generate a "they-they" classification, and for that matter a classification that facially disadvantages the legislative majority but was intended, and will function, as a de facto they-they classification. Thus, there might be reason to believe that a law that apparently favors Blacks over Whites was specifically intended to disadvantage a subset of Whites that is both inadequately represented in the decision making body and the object of unusual prejudice. But where there is no reason to suspect that the comparative disadvantage will not be distributed evenly throughout the "we" class, a we-they classification that favors the "they"s does not merit "special scrutiny"-though obviously the court should take a careful look to make sure that the case presented fits this description. ${ }^{50}$ Whether or not it is more blessed to give than to receive, it is surely less suspicious.

\section{III}

Even if one accepts this conclusion in a vacuum, its adoption and enforcement by the courts, particularly by the United States Supreme

49 But see Otero v. New York City Housing Auth., 484 F.2d 1122 (2d Cir. 1973). Of course, a practice like that involved in DeFunis may well hurt Blacks in some ways: it may insult them or serve to undercut the value of their degrees. But where it is clear, as I think it is here, that the package as a whole advantages Blacks relative to Whites, and, moreover, that everyone assumed it would, the danger that the majority is simply legislating in its own self-interest is largely absent.

Some might claim that busing plans whose participants are selected by race are not suspect, by arguing that we can easily tell from the statistics which race is being injured more, or perhaps that the hurt, though real, is comparatively trivial. But the problems with busing cannot be so easily waved away. $C f$. text at notes 8-11 supra. The more candid approach is to admit that these classifications are suspect, because they do not fall within the relatively small subset of racial classifications as to which it is clear that the majority is comparatively disadvantaging itself in favor of a minority. It can then be argued, however, that special scrutiny is satisfied, because (1) the goal-integration in the sense of homogenization and not, say, increasing the percentage of Blacks in a given profession-would be nonsuspicious no matter who fixed upon it (and was specifically approved in Brown), and (2) the racial classification employed fits that goal perfectly, not approximately. Every White bused into a predominantly Black school, and every Black bused into a predominantly White school, promotes racial integration irrespective of his other characteristics. See note 26 supra.

60 See text at notes $51-53$ infra. 
Court, would entail some difficulties and side effects that are troublesome at the least, and might even suggest that a prophylactic rule banning all racial classification is the better course. The concern may be that a preference for one minority may not operate to the undifferentiated disadvantage of the majority generally, but instead may cause disproportionate harm to a discrete, disfavored, and relatively powerless subset of the majority. This is not, of course, an argument invented for purposes of this discussion: just such a fear has prompted certain Jewish groups to voice strenuous opposition to preferential admissions for Blacks. Somehow, the concern seems to run, most of those "Black places" will be taken from Jews. I do not for a moment discount the reality of anti-Semitism in our society, nor can we consider the feared scenario "just one of the costs" of pursuing racial equality. It is an unacceptable scenario, and an unconstitutional one as well. An American state legislature, unlike, perhaps, the Israeli Parliament, cannot legitimately pursue the goal of reducing the percentage of Jewish lawyers. ${ }^{51}$ Whites generally, not Jews in particular, are a majority in our society, and consequently racial discrimination is unsuspicious only when it runs against whites in general. ${ }^{52}$

It is questionable, however, whether this danger can form the basis for a constitutional argument against preferences for Blacks or other racial minorities. A "discretionary" system of selection already leaves room for various sorts of indefensible prejudice to operate: no matter how one might feel about the comparative merits and dangers of such a system-my own feeling has never been very positive-a decision to extend preferences to Blacks does not significantly alter the problem. Administrators who incline toward anti-Semitism in the one situation will very likely incline toward it in the other. The chances of catching them, of demonstrating the illegality of what they are doing, are no greater in the one than in the other. And if a preferential admissions program for Blacks should be accompanied by an unexplained disproportionate drop in the percentage of Jews, or even by a shift to a

51 But cf. note 59 infra. The example sounds less bizarre when one bears in mind that a decision to increase the percentage of Black lawyers is necessarily a decision to decrease the percentage of White lawyers.

52 It seems quite clear that no particular ethnic subset of Whites experiences a disproportionate disadvantage under existing law school preferential admissions programs for Blacks. The applicants who would have been admitted but for such programs seem to be united by nothing more exciting than their mediocre predicted grade averages. Jews are competing for, and sometimes lose, the seats in question, but the number is proportionate to the percentage they comprise of the entire White applicant pool.

Of course, other sorts of schools do not rely as heavily on predicted performance; consequently, more play is allowed for discretion and hunch. Furthermore, even law schools could change their procedures. Thus, the danger mentioned in the text does exist. 
selection system that left more room for anti-Semitism-a more discretionary system or a ceiling on the number of students from New York City-the appropriate judicial response would be clear. There would be reason to suspect that the idea was to prefer one ethnic minority at the disproportionate expense of another for reasons of religious prejudice, and the scheme should be invalidated. Anti-Semitism is a danger-one that should, in any event, be combatted by every available tool, including constitutional litigation-but the danger is independent of a decision to extend preferences to Blacks. Perhaps in other situations it will be impossible ever confidently to conclude that the dominant majority is not favoring Blacks over some White minority for reasons of ethnic prejudice. But as long as there are situations where the two problems are separable-and this seems to be the case in the law school situation in which DeFunis arose-an across-the-board ban on preferential treatment seems unjustified.

Some of us used to worry that any employment by the government of racial classifications for "benign" purposes-particularly with the Supreme Court's legitimation-would retard public acceptance and enforcement of decisions like Brown $v$. Board of Education. ${ }^{53}$

[T]he government's intentional and explicit use of race as a criterion of choice is bound-no matter how careful the explanation that this is a "good" use of race-to weaken the educative force of its concurrent instruction that a man is to be judged as a man, that his race has nothing to do with his merit. Citizens, thus beseiged by what will understandably be taken to represent two conflicting government-endorsed principles, are likely to listen to the voice they wish to hear. ${ }^{54}$

The concern might have carried the day so long as there was reason to hope that simply removing racial access barriers would result in genuine integration of society's various institutions. Although the barriers have not yet been entirely removed-heated debate on "benign" discrimination must not fool us into believing that malign discrimination is a thing of the past-we have enough experience to suggest that an "open door" is not sufficient, that if we are to have any hope of defeating racial prejudice we will have to take race into account for some pur-

53347 U.S. 483 (1954).

54 Ely, supra note 6 , at 1259 . That article pushed the point only to the extent of arguing that the Court should not force states to consider race in drawing various lines; but it might be pushed further, to the conclusion that states should not be allowed to do so. Kaplan, Equal Justice in an Unequal World: Equality for the Negro-The Problem of Special Treatment, 61 Nw. U.L. REv. 363 (1966), contains an unusually sensitive presentation of this viewpoint. 
poses. And if that is the course we are to take, then that is the message we will have to project, difficult though it may be to expose the "contradiction" as only apparent.

Governmental use of benign racial classifications may destroy blinding myths by teaching people that race is indeed a factor of great importance in our society and that many people are now disadvantaged because of past and continuing racial discrimination. These measures may illustrate that in appraising individuals for many purposes race cannot be ignored if the appraisal is to bear a realistic relation to the person's circumstances .... ${ }^{55}$

The question is whether the negative educative effects of using racial criteria to overcome centuries of discrimination are so inevitable, and indeed so threatening, as to outweigh the good that such programs may accomplish. It is a difficult question, but the basis for an affirmative answer can hardly be secure enough to support an absolute declaration of constitutional impermissibility. ${ }^{58}$

A credible explanation of why "benign" racial classifications are not suspect, however, would require the Court to expose some of the considerations that have made malign racial classifications suspect, and that exposure poses arguable risks for the judicial process. Explaining that the Court has accorded special review to most racial classifications because they are often the product of irrational prejudice might prompt a charge that the Court builds its constitutional judgments on "sociology, not law."'s7 Even if the Court could sidestep that charge with an explanation phrased more in terms of the relative nonsuspiciousness of a group's decision to disadvantage itself in favor of another, it would still find itself in sensitive territory. The Justices might feel awkward about publicly taking into account the racial or other composition of the decision making body, or perhaps of its constituency, ${ }^{68}$ even assum-

55 Developments, supra note 7, at 1113 .

56 "It may be that actual participation of blacks in positions alongside whites will ultimately prove to have the most important and long-lasting educative effect against discrimination." Id.

57 Of course, the development of constitutional doctrine has often, and properly, taken societal interests into account, and there is nothing unusually controversial here. The Court's tactical error in Brown seems to have been the citing of books. But the experience there suggests the possibility of the reaction.

58 I would have thought the point too obvious to warrant mention, but it has so often been put to me as an "embarrassing question" that perhaps I had better answer it. Of course it works both ways: a law that favors Blacks over Whites would be suspect if it were enacted by a predominantly Black legislature.

There is a problem when the decision making body is predominantly composed of the class advantaged by the legislation, but its constituency is not. This presents no difficulty in a case like DeFunis: the Washington legislature is heavily White and so is the state as 
ing that the pertinent facts are obvious. ${ }^{58}$ As far back as 1879 the Court, in a passage that indeed begins to hint at the analysis suggested in this paper, indicated that it saw no particular impropriety in such a reference:

If in those States where the colored people constitute a majority of the entire population a law should be enacted excluding all white men from jury service, thus denying to them the privilege of participating equally with the blacks in the administration of justice, we apprehend no one would be heard to claim that it would not be a denial to white men of the equal protection of the laws. ${ }^{60}$

Perhaps there is more unseemliness here than met the Court's eye, but it seems insufficient to justify a broad "prophylactic" rule that would deny the states the power to pursue a vision of racial equality with positive action.

a whole. (And so, as Chief Justice Hale needled in dissent-not realizing he was walking into my little trap-is the faculty of the University of Washington Law School: "This policy of ethnic minority selection apparently was not to apply to faculty positions." 82 Wash. 2d at 51, 507 P.2d at 1192.) The question obviously arises in connection with discrimination against women: all our legislatures are overwhelmingly male, but women comprise a majority of the voting population. Should we be suspicious nonetheless of the unconscious biases of male legislators when they enact legislation upon the assumption that women are in certain ways less qualified than men, or rather conclude that women should simply vote the rascals out if they don't like what is being done to them? I would reject the latter response. (Voters typically are not confronted with single issue referendums but rather with packages of views that we call candidates. Cf. Tullock, Problems of Majority Voting, 67 J. Por. Econ. 571 (1959). Most women are not injured in an obvious way by laws that classify on the basis of sex, and the fact that they elect representatives who are unprepared to repeal these laws means only that there are other issues about which they feel more strongly.) But the issue is by no means trivial.

60 If the facts about the legislature's composition are not obvious, a racial or similar classification should be regarded as suspicious. Evidentiary hearings on the issue would appear inappropriate. It is obvious, however, that as of 1974 the legislature of every American state is overwhelmingly White, male, native born, and comfortably above the poverty line. The predominantly Protestant cast of most state legislatures seems beside any constitutional point, given that the combination of the establishment and free exercise clauses, read responsibly, precludes the comparative favoring or disfavoring of any religion. See Ely, supra note 6, at 1313-27. But cf. Wisconsin v. Yoder, 406 U.S. 205 (1972); Sherbert v. Verner, 374 U.S. 398 (1963).

60 Strauder v. West Virginia, 100 U.S. 303, 308 (1879). The passage is cited for its hint that equal protection might be a function of who is doing the discriminating, and not for its specific point. For the jury situation seems special in that the litigant's interest in procedural due process requires a jury from which members of his own race have not been systematically excluded, irrespective of whether his race is a majority in the community at large. (It is entirely possible, of course, that the Court alluded to a Black majority only because it assumed there were no other circumstances under which a law comparatively disadvantaging Whites would be enacted.) 
Those who are troubled would be better advised to consider another alternative, eloquently elaborated in the earlier writings of Professor Bickel (indeed, "benevolent quotas" were one of his chief examples"): denial of review. Powerful attacks have been mounted on the use of the "passive virtues" to avoid the invalidation of practices that are wrong on constitutional principle. ${ }^{62}$ The use suggested here is different, however, ${ }^{83}$ and is addressed to anyone who takes the (debatable) view that although the practice in question is not unconstitutional on principle, explaining why it is not would carry serious costs for the nation generally and the Court in particular.

By virtually inviting another DeFunis case, the Court seems to have indicated that it sees no great costs in writing the opinion, and I am inclined to agree. But that decision-and not the decision on the constitutional merits-is the hard one. Measures that favor racial minorities pose a difficult moral question that should, by one method or the other, be left to the states. There is nothing suspicious about a majority's discriminating against itself, though we must never relent in our vigilance lest something masquerading as that should in fact be something else.

61 A. BickeL, supra note 25, at 61, 71-72, 174.

62 See Gunther, The Subtle Vices of the "Passive Virtues"-A Comment on Principle and Expediency in Judicial Review, 64 Colum. L. Rev. 1 (1964).

03 But see Kaplan, supra note 54, at 409-10. 